\section{Nutsedge Control with Drip-applied 1,3-Dichloropropene plus Chloropicrin in a Sandy Soil}

\author{
Carlene A. Chase ${ }^{1,5}$, William M. Stall ${ }^{1}$, Eric H. Simonne ${ }^{1}$, \\ Robert C. Hochmuth ${ }^{2}$, Michael D. Dukes ${ }^{3}$, and \\ Anthony W. Weiss ${ }^{4}$
}

AdDITIONAL INDEX wORDs. chemigation, soil fumigant, InLine, Cyperus rotundus, Cyperus esculentus, methyl bromide alternative, high-density polyethylene film, virtually impermeable film, plastic mulch

Summary. An evaluation of the effect of bed width $(24,28,32$, and 36 inches) on the control of a mixed population of nutsedge [yellow nutsedge (Cyperus esculentus) and purple nutsedge (C. rotundus)] was conducted with an emulsifiable concentrate formulation of a 1,3-dichloropropene (1,3-D) and chloropicrin (CP) mixture (1,3-DCP) for application through drip irrigation systems. Beds were mulched with either 1.4-mil-thick virtually impermeable film (VIF) or 0.75-mil-thick high-density polyethylene (HDPE) and 1,3-DCP was applied at $35 \mathrm{gal} /$ acre by surface chemigation or via subsurface chemigation 6 inches deep within the bed. HDPE was more permeable to gaseous $1,3-\mathrm{D}$ than VIF so that 1 day after treatment (DAT), 1,3-D gas concentration at the bed centers under VIF was significantly higher than under HDPE. Dissipation of 1,3-D gas with HDPE occurred within 7 DAT, but dissipation with VIF took $\sim 10$ days. In bed centers, 1,3-D concentrations 1 DAT were in the range of 2.3 to $2.9 \mathrm{mg} \cdot \mathrm{L}^{-1}$ whereas in bed shoulders concentrations ranged from 0.1 to $0.55 \mathrm{mg} \cdot \mathrm{L}^{-1}$. In 2002 and $2003,1,3-D$ concentration in shoulders of narrower beds was significantly higher than in the wider beds, but dissipated more rapidly than in wider beds. Lower initial 1,3-D concentrations were observed with HDPE film in shoulders than with VIF and the rate of dissipation was lower with VIF. At 14 DAT, nutsedge plants were densely distributed along bed shoulders ( 19 to 27 plants $/ \mathrm{m}^{2}$ ) with little or no emergence in the centers of beds (fewer than 5 plants $/ \mathrm{m}^{2}$ ), but with no response to bed width. Nutsedge density increased with time, but the nature of the increase differed with bed width. The most effective nutsedge suppression was achieved with 36-inch beds, which had densities of $11-13$ plants $/ \mathrm{m}^{2}$ on bed centers and 53 plants $/ \mathrm{m}^{2}$ on bed shoulders by 90 DAT. Nutsedge suppression was initially more effective with VIF than with HDPE film, so that no nutsedge emerged in the centers of beds mulched with VIF compared with 2-7 plants/ $\mathrm{m}^{2}$ with HDPE by 14 DAT. On bed shoulders there were $2-7$ plants $/ \mathrm{m}^{2}$ with VIF and 32-57 plants $/ \mathrm{m}^{2}$ with HDPE. Increase in nutsedge density with time was greater with VIF so that by 90 DAT nutsedge densities on bed centers and shoulders were greater than with HDPE in 2002 and the same as with HDPE in 2003. Subsurface chemigation did not consistently improve suppression of nutsedge when compared with surface chemigation. Concentrations of $1,3-\mathrm{D}$ in bed shoulders irrespective of bed width were nonlethal. Initial superior nutsedge suppression with VIF did not persist. Nutsedge control in a sandy soil with 1,3 DCP chemigation is unsatisfactory with one drip-tape per bed.
Acknowledgments: Technical assistance was provided by Michael Alligood, Wayne Davis, Scott Kerr, Wanda Laughlin, Jill Meldrum, John Mirusso, and David Studstill and statistical consulting by Meghan Brennan. This research was supported by a grant from the Florida Fruit and Vegetable Research Foundation.

${ }^{1}$ Horticultural Sciences Department, University of Florida, Gainesville, FL 32611 .

${ }^{2}$ North Florida Research and Education Center-Suwannee Valley, Live Oak, FL 32060

${ }^{3}$ Agricultural and Biological Engineering Department, University of Florida, Gainesville, FL 32611

${ }^{4}$ Dow Agrosciences, Cary, NC 27513.

${ }^{5}$ To whom correspondence should be addressed; e-mail address: cachase@ufl. edu.
$\mathrm{C}$ hisel-applied volatile formulations of the soil fumigant mixture 1,3-DCP are among the more promising alternatives to methyl bromide for crop production (Locascio et al., 1997). 1,3-DCP is already registered for use in plasticulture production of vegetables and strawberry (Fragaria xananassa) in Florida for the control of plant pathogenic nematodes and soilborne pathogens. Its effect on nutsedges is weak or inconsistent when compared with methyl bromide. Under some conditions, the resulting concentrations of the fumigant and duration of exposure appear to be sufficient to provide adequate control of nutsedge (Hochmuth et al., 2002). However, this is not always the case and these conditions are not well understood. Hence, one approach to controlling purple nutsedge has utilized fumigant / herbicide combinations (Gilreath and Santos, 2004a, 2004b, 2005; Gilreath et al., 2004). In laboratory studies the effective concentration of $1,3-\mathrm{D}+17 \%$ chloropicrin resulting in $50 \%$ mortality of imbibed yellow nutsedge tubers was $20 \mu \mathrm{M}$ (Hutchinson et al., 2004); while in greenhouse studies, 99\% mortality of imbibed yellow nutsedge tubers was obtained with $327 \mathrm{~L} \cdot \mathrm{ha}^{-1}$ $1,3-\mathrm{D}+35 \%$ chloropicrin (Motis et al., 2002). We hypothesized that the failure to achieve consistent results on nutsedges with 1,3-D-containing fumigants in the field may be due to insufficient duration of exposure to lethal concentrations.

Drip fumigation is a relatively new concept and Ajwa et al. (2002) identified a number of areas in which more work is needed: minimizing application rates; selecting mulches that restrict emissions and maximize efficacy; and optimum soil conditions, carrier amounts, and combinations of chemicals. Benefits of applying soil fumigants by chemigation include limited worker exposure since installation of polyethylene film is done prior

\begin{tabular}{llll}
\hline $\begin{array}{l}\text { Units } \\
\text { To convert U.S. to SI, } \\
\text { multiply by }\end{array}$ & U.S. unit & SI unit & $\begin{array}{l}\text { To convert SI to U.S., } \\
\text { multiply by }\end{array}$ \\
\hline 0.3048 & $\mathrm{ft}$ & $\mathrm{m}$ & 3.2808 \\
0.0929 & $\mathrm{ft}^{2}$ & $\mathrm{~m}^{2}$ & 10.7639 \\
3.7854 & $\mathrm{gal}$ & $\mathrm{L}$ & 0.2642 \\
9.3540 & gal/acre & $\mathrm{L} \cdot \mathrm{ha}^{-1}$ & 0.1069 \\
2.54 & inch(es) & $\mathrm{cm}$ & 0.3937 \\
0.0254 & mil & $\mathrm{mm}$ & 39.3701 \\
1 & $\mathrm{ppm}$ & $\mathrm{mg} \cdot \mathrm{L}^{-1}$ & 1 \\
6.8948 & $\mathrm{psi}$ & $\mathrm{kPa}$ & 0.1450
\end{tabular}


to the application and the capability of simultaneous or sequential application of fumigants (Desaeger et al., 2005). Sequential application would be applicable to Florida plasticulture systems in which growers plant multiple crops in sequence using the same beds and polyethylene film. A third benefit is that drip application of emulsifiable concentrate formulations of 1,3-DCP is generally considered less susceptible to off-gassing than shank application of volatile, liquid formulations. Wang et al. (2001) reported lower emissions of 1,3-D with drip fumigation than with shank fumigation. As a result, buffer zones between application sites and any occupied buildings for volatile, liquid formulations were initially three times that for drip-applied formulations.

Limiting emissions is desirable for reducing the possibility of human and animal exposure. Also, strategies that result in higher soil fumigant concentrations as a consequence of limiting emissions can enhance the effectiveness of the fumigation. Wang et al. (2001) advocated the following approaches to reduce 1,3-D emissions: improved containment with impermeable mulches, application at increased soil depth, and reduced application rates. Containment refers to achieving a fumigant dose and exposure time that deliver effective pest control (Yates et al., 2002). Measures that result in fumigant containment reduce emissions, and consequently require less fumigant to be applied for similar level of pest control (Santos et al., 2005). VIFs consist of an impermeable barrier layer of ethylene vinyl alcohol or polyamide sandwiched between polyethylene (Yates et al., 2002). VIF use resulted in improved containment and reduced emissions of methyl bromide (MB) and alternative fumigants in California, when the entire field (not just beds) was covered during fumigation (Wang et al., 1999). In addition, Nelson et al. $(2000,2001)$ found that VIF-mulched beds retained higher concentrations of 1,3-D and had significantly lower emissions than no mulch controls and beds mulched with low-density polyethylene film during the $3 \mathrm{~d}$ following application.

Florida's plasticulture production system involves fumigant application to pre-formed beds that are then covered with polyethylene film. The film serves as a fumigation tarp and is retained as a production mulch. VIF is not as effec- tive in reducing emissions when used only on beds (Wang and Yates, 1998) since fumigants may be lost through lateral movement into the unmulched furrows. However, application only to the beds reduces the amount of fumigant and film that must be used, since application rates are based on treated surface area.

Csinos et al. (2002) have described a method of using dye to visualize the wetting pattern produced by drip irrigation emitters in polyethylenemulched beds. In the deep sands in Florida, growers typically use one drip tape per bed, placed in the center of the bed for crops planted in two rows and slightly off-center for crops planted in a single row. Depending on fumigant volatility and the concentrations of gas that can be achieved in zones of the bed that remain dry, it may be possible to achieve lethal concentrations with chemigation. However, pest control may be inadequate with less volatile fumigants if the entire bed is not wetted. The objective of this study was to evaluate the effect of bed width, drip tape placement, and mulch film type on 1,3-DCP soil distribution and nutsedge control in a sandy soil. We hypothesized that decreasing bed width and use of subsurface chemigation and VIF would result in more effective nutsedge control by concentrating the fumigant in a smaller soil volume and enhancing fumigant containment.

\section{Materials and methods}

Experiments were conducted at the North Florida Research and Education Center-Suwannee Valley, near Live Oak, on a Lakeland fine sand (thermic, coated Typic Quartzipsamments) in Fall 2002 and 2003. Plots were 70 $\mathrm{ft}$ long and were located in a field with a high purple nutsedge infestation. The soil fumigant $1,3-\mathrm{D}(60.8 \%)$ plus chloropicrin (33.3\%) (InLine; Dow Agrosciences, Indiananpolis) was applied as a chemigation treatment to beds with a range of widths that encompass widths generally used for vegetable production in Florida: 24, 28,32 , and 36 inches. In 2002 , soil was hilled into false beds prior to pressing with a bed-shaper equipped with an adjustable-width press pan (Kennco Manufacturing, Ruskin, Fla.). In 2003, a Kennco one bed bed-shaper with interchangeable fixed-width press pans was used. Beds were 6 inches high. A single drip-irrigation tape (Ro-Drip;
Roberts Irrigation Products, San Marcos, Calif.) with emitters spaced at 12 -inch intervals and a flow rate of 24 $\mathrm{gal} / \mathrm{h}$ per $100 \mathrm{ft}$ at 12 psi was installed along the center of each bed either at the soil surface or buried 6 inches within the bed. Two white-on-black films with the white side up were used to mulch the beds: 1.4-mil-thick VIF (Hytibarrier, Klerks, Richburg, S.C.) and 0.75 -mil-thick HDPE (Sonoco, Hartsville, S.C.).

The experimental design was a split plot with bed widths allocated to main plots in a randomized completeblock design with six replications. Four film type/drip-tape depth combinations were assigned to the subplots in a completely randomized manner: HDPE, 0 inch; HDPE, 6 inches; VIF, 0 inch; and VIF, 6 inches. 1,3-DCP was applied through the drip irrigation system at $35 \mathrm{gal} / \mathrm{acre}$ on $15 \mathrm{Aug}$. 2002 and 28 Aug. 2003. In accordance with U.S. Environmental Protection Agency requirements, the rate of dripapplied fumigants is based on the bed width. Therefore, the wider the bed the larger the amount of fumigant that must be applied and thus the longer the duration of application. Duration of application was $240,280,320$, and 360 min for 24-, 28-, 32-, and 36-inch bed widths, respectively. Water-soluble blue dye (Terramark SPI High Concentrate; ProSource One, Memphis, Tenn.) was injected immediately prior to the soil fumigant to permit visualization of the extent of the wetting pattern of the fumigant (Csinos et al., 2002). In each block, two nontreated control plots were also included, one of which was mulched with VIF and the other with HDPE film.

Efficacy of soil fumigant application was evaluated by monitoring soil gas concentration until $15 \mathrm{~d}$ after treatment (DAT) and by monitoring the density of a mixed population of purple and yellow nutsedge 14, 28, 60, and 90 DAT. Soil air was sampled using Gastec trichloroethylene detector tubes (132HA; Zefon International, St. Petersburg, Fla.) and a gas tube pump (Sensidyne, Clearwater, Fla.) to detect $1,3-\mathrm{D}$ at $10-\mathrm{cm}$ depth at the center and the shoulder of each bed. Nutsedge plants that emerged through the mulch films were counted on $14,28,60$, and $90 \mathrm{~d}$ after fumigant application. Counts were performed on a 10 -ft-long section of each plot. Separate counts were performed for the 
bed shoulders and bed centers. From prior experience in sandy soils, the wetted width of the bed is narrower than the width of the bed because of limited lateral movement away from the drip tape. It was anticipated that some of the plots would have nutsedge occurring only in the bed shoulders. Therefore, bed shoulders were held constant and defined as 6-inch-wide strips along the edges of the bed. The rest of the bed was considered the bed center and was $12,16,20$, and 24 inches wide for the 24-, 28-, 32,- and 36-inch bed widths, respectively.

Data analysis was performed using the MIXED procedure of SAS (version 9.0; SAS Institute, Cary, N.C.). Repeated measures analysis was utilized for gas and nutsedge data, which were collected at multiple intervals. Linear and quadratic responses to changing bed width and over time were evaluated using orthogonal polynomials. PROC IML was used to generate coefficients for orthogonal polynomials for the unevenly spaced time intervals. Nutsedge counts were square-root transformed prior to data analysis. The DIFF option was used to obtain comparisons between pairs of least squared means. Untransformed least squared means were used in the tables for ease of interpretation. Regression of wetting pattern measurements was done using PROC REG.

\section{Results and discussion}

As can be expected, for both bed centers and bed shoulders, gaseous 1,3-D concentration was highest immediately after application and declined with time.

1,3-D CONCENTRATION IN BED CENTERS. In 2002, the main effect of bed width on 1,3-D in soil gas sampled at bed centers was nonsignificant. The concentrations of $1,3-\mathrm{D}$ were 0.4 , $0.403,0.468$, and $0.474 \mathrm{mg} \cdot \mathrm{L}^{-1}$ for 24-, 28-, 32-, and 36-inch-wide beds, respectively, and not statistically different (data not shown). At 1,4 , and 7 DAT, concentration of $1,3-\mathrm{D}$ with VIF was higher at bed centers than with HDPE, indicating more rapid dissipation of the soil fumigant with HDPE (Fig. 1). By 1 DAT, 1,3-D concentration at the bed centers under VIF was $\sim 2 \mathrm{mg} \cdot \mathrm{L}^{-1}$, twice the concentration under HDPE. By 7 DAT, 1,3-D was no longer detectable under HDPE film, whereas there was more gradual dissipation with VIF until 10 DAT. There was no statistical difference in soil gas concentrations between surface and subsurface chemigation.

In 2003 , the effect of film type and depth of chemigation differed with bed width $(P<0.01)$. Initial concentrations of gaseous $1,3-\mathrm{D}$ in the soil 1 DAT measured at the center of the beds mulched with VIF were 2.3 to 2.9 $\mathrm{mg} \cdot \mathrm{L}^{-1}$ and generally higher than with HDPE (Fig. 2). As for 2002, the rate of loss of 1,3-D gas from the soil occurred more rapidly with HDPE. Therefore, 1,3-D was completely dissipated by 7 DAT with HDPE compared with 8-10 DAT with VIF. With HDPE, subsurface chemigation resulted in higher concentrations of $1,3-\mathrm{D}$ with 24-, 28-, and 32 -inch beds 1 DAT $(P$ $\leq 0.04$ ). Subsurface drip chemigation with VIF resulted in similar 1,3-D gas concentrations as surface chemigation except for 32 -inch beds, which had lower 1,3-D gas concentration with subsurface chemigation $(P=0.003)$.

1,3-D CONCENTRATION IN BED SHOULDERS. The initial concentrations of $1,3-\mathrm{D}$ in bed shoulders were five-fold lower than in the bed centers ranging from 0.1 to $0.55 \mathrm{mg} \cdot \mathrm{L}^{-1}$ ( Fig. $3)$. The effect of bed width on soil gas concentration in bed shoulders varied with time. In both years, concentrations of $1,3-\mathrm{D}$ gas at 1 DAT were similar in 24- and 28 -inch beds $(P>$ $0.05)$. Also, the concentrations in the bed shoulders of these narrower beds were higher than in the wider beds $(P$ $\leq 0.002$ ) in both years. This can be attributed to the shoulders of wider beds being further away from the driptape than in narrower beds. In 2002, initial 1,3-D concentrations in 32- and 36-inch beds were statistically similar $(P>0.05)$; however, in $20031,3-\mathrm{D}$ concentration was higher in 32-inch beds than in 36-inch beds $(P=0.03)$. In both years, 1,3-D concentration declined in a quadratic manner with the narrower bed widths and linearly with the wider bed widths, with more rapid dissipation occurring with the narrower bed widths.

As for bed centers, HDPE film was more permeable to gaseous $1,3-\mathrm{D}$ at bed shoulders than VIF (Fig. 4). Initial 1,3-D concentrations at bed shoulders with VIF I DAT were significantly higher than under HDPE $(P<0.01)$. Loss of 1,3-D was faster with HDPE so that complete dissipation had occurred by 7 DAT, whereas $0.2-0.3$ $\mathrm{mg} \cdot \mathrm{L}^{-1}$ could still be detected under VIF. Subsurface chemigation did not result in differences in 1,3-D concentration in bed shoulders in 2002. In 2003 , subsurface chemigation with VIF resulted in lower levels of 1,3-D gas at 1 DAT than surface chemigation

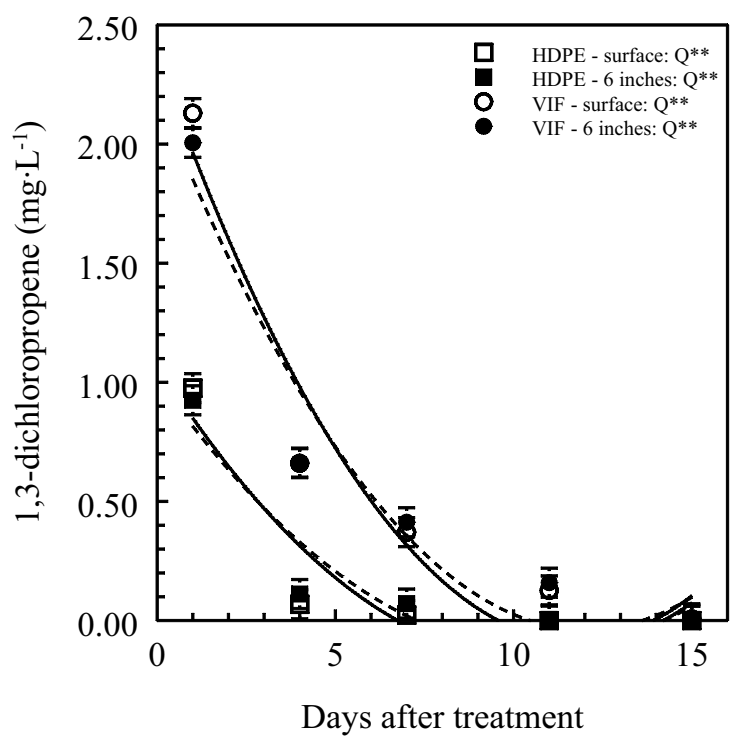

Fig. 1. Concentration of 1,3-dichloropropene at bed center of a sandy soil as affected by film type and depth of chemigation in 2002. Data were averaged over bed width. HDPE and VIF are 0.75 -mil high-density polyethylene film and 1.4mil virtually impermeable film, respectively. $Q^{* *}$ indicates a quadratic trend significant at $P<0.01$. Solid and dashed lines indicate surface and subsurface chemigation, respectively; $1 \mathrm{mil}=0.0254 \mathrm{~mm}, 1 \mathrm{mg} \cdot \mathrm{L}^{-1}=1 \mathrm{ppm}, 1$ inch $=2.54 \mathrm{~cm}$. 


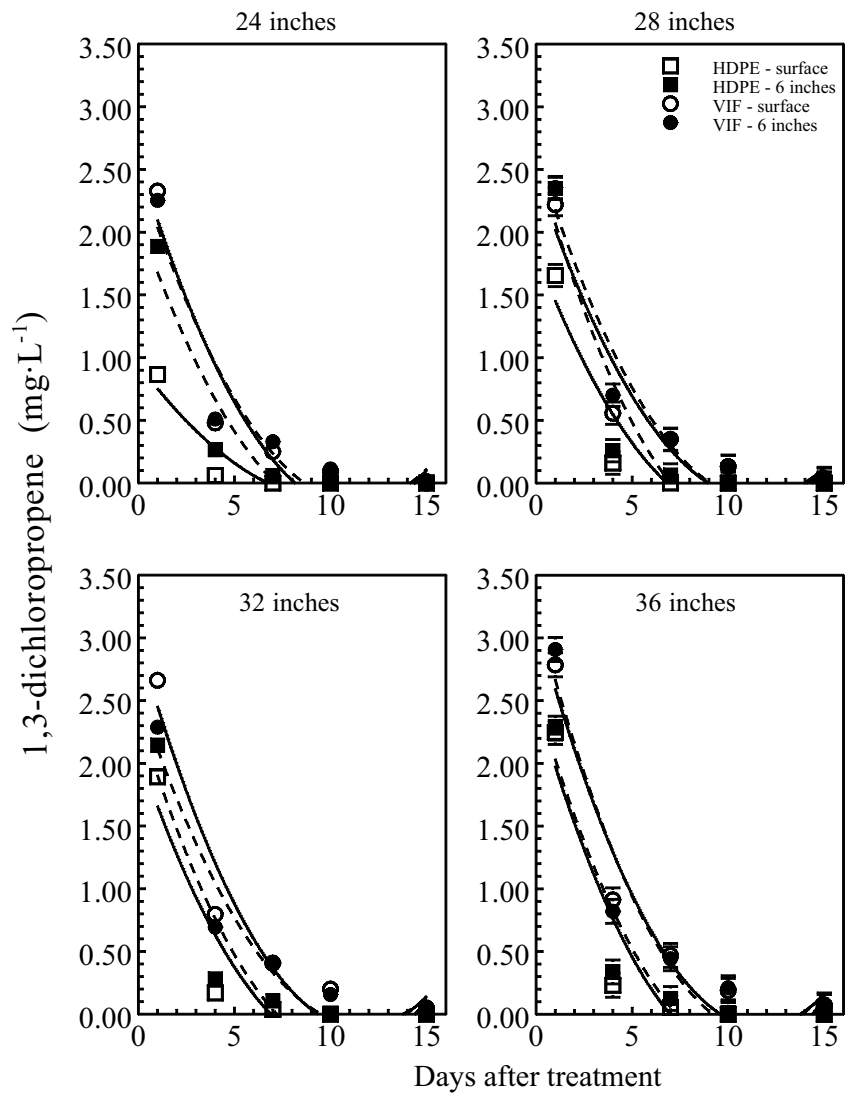

Fig. 2. Concentration of 1,3-dichloropropene at bed center of a sandy soil as affected by film type and depth of chemigation in 2003. HDPE and VIF are 0.75 -mil high-density polyethylene film and 1.4-mil virtually impermeable film, respectively. All responses had a significant quadratic trend $P<0.01$ as determined by orthogonal polynomials; $1 \mathrm{mil}=$ $0.0254 \mathrm{~mm}, 1 \mathrm{mg} \cdot \mathrm{L}^{-1}=1 \mathrm{ppm}, 1$ inch $=2.54 \mathrm{~cm}$.

$(P<0.01) .1,3-\mathrm{D}$ gas concentration with surface chemigation and HDPE film was close to detection limits 1 DAT and was undetectable by 4 DAT. Subsurface chemigation HDPE resulted in $\sim 0.15 \mathrm{mg} \cdot \mathrm{L}^{-1} 1,3-\mathrm{D}$, with complete dissipation by 7 DAT. Our results of indicate greater 1,3-D concentration with VIF than with HDPE film and greater concentrations of $1,3-\mathrm{D}$ in the center of the beds than in bed shoulders. Similar results were obtained in previous studies (Ajwa et al., 2002; Papiernik et al., 2004).

Nutsedge CONTROL WITH 1,3DCP AS AFFECTED BY BED WIDTH. In 2002, by 14 DAT fewer than 3 plants $/ \mathrm{m}^{2}$ were observed in the centers of beds and nutsedge density did not differ with bed width (Table 1). At subsequent evaluation dates, nutsedge density in bedcenters decreased linearly as bed width increased. The rate of increase in nutsedge density over time was greater in narrower beds $(24$ and 28 inches) than in the wider beds ( 32
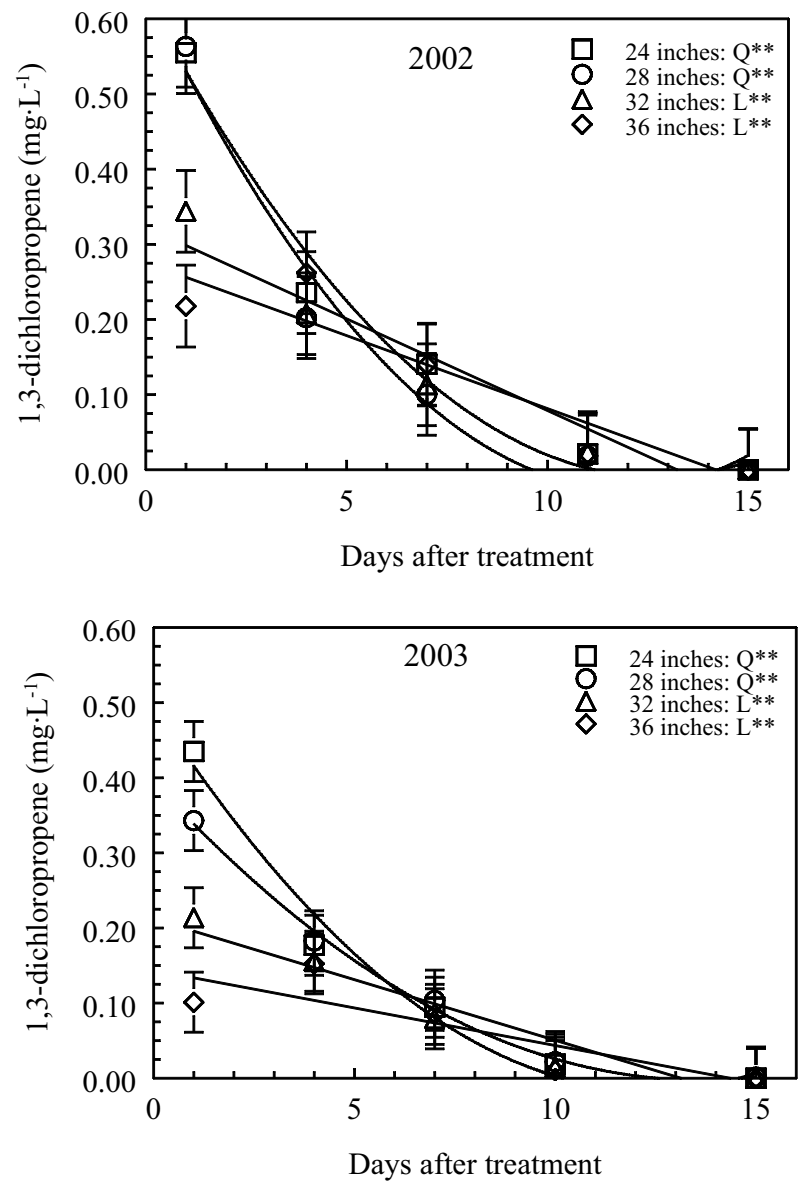

Fig. 3. Effect of bed width on 1,3-dichloropropene concentration in bed shoulders of a sandy soil. $L^{* *}$ and $Q^{* *}$ indicate linear and quadratic responses significant at $P \leq$ 0.01 as determined by orthogonal polynomials; $1 \mathrm{mg} \cdot \mathrm{L}^{-1}=$ $1 \mathrm{ppm}, 1$ inch $=2.54 \mathrm{~cm}$.

and 36 inches). By 60 and 90 DAT nutsedge densities in bed centers were highest with 24 -inch beds ( 32.5 and 42.7 plants $\left./ \mathrm{m}^{2}\right)$, intermediate with 28 inch beds ( 21.3 and 26.4 plants $/ \mathrm{m}^{2}$ ), and lowest with the $32-(8.4$ and 17.4 plants $/ \mathrm{m}^{2}$ ) and 36 -inch beds (6.3 and 10.8 plants $\left./ \mathrm{m}^{2}\right)$. Higher nutsedge infestation occurred in the bed shoulders than in the bed centers. By 14 DAT nutsedge densities in bed shoulders ranged from 19.2 to 29.2 plants $/ \mathrm{m}^{2}$, but with no significant difference due to bed width. As for the bed centers, there was a linear decrease in nutsedge density with increasing bed width at 28,60 , and 90 DAT. The rate of increase of nutsedge density was also greater in 24- and 28-inch beds than in 32 - and 36-inch beds. By 90 DAT nutsedge density was highest on shoulders 24 -inch beds ( 120 plants $\left./ \mathrm{m}^{2}\right)$, intermediate with 28 -inch beds ( 104 plants $/ \mathrm{m}^{2}$ ) and lowest with 32 - and 36-inch beds (94 and 53 plants $/ \mathrm{m}^{2}$, respectively).

In 2003 , as for 2002 , no differences in nutsedge density in response to bed width were apparent on the centers and shoulders of beds by 14 DAT (Table 1). However, whereas with bed centers at 28,60, and 90 DAT nutsedge density decreased as bed width increased, significant suppression of nutsedge density on bed shoulders was only apparent at 60 and 90 DAT. Nutsedge density in bed centers increased in a quadratic manner over time with all bed widths, but the rate of increase was highest with 24inch beds, intermediate with 28 - and 32 -inch beds, and lowest with 36-inch beds. Along bed shoulders nutsedge density also increased quadratically over time. However, the rate of increase was similar with 24-, 28-, and 32 -inch beds, whereas nutsedge density increased at a lower rate with 36 -inch beds. 

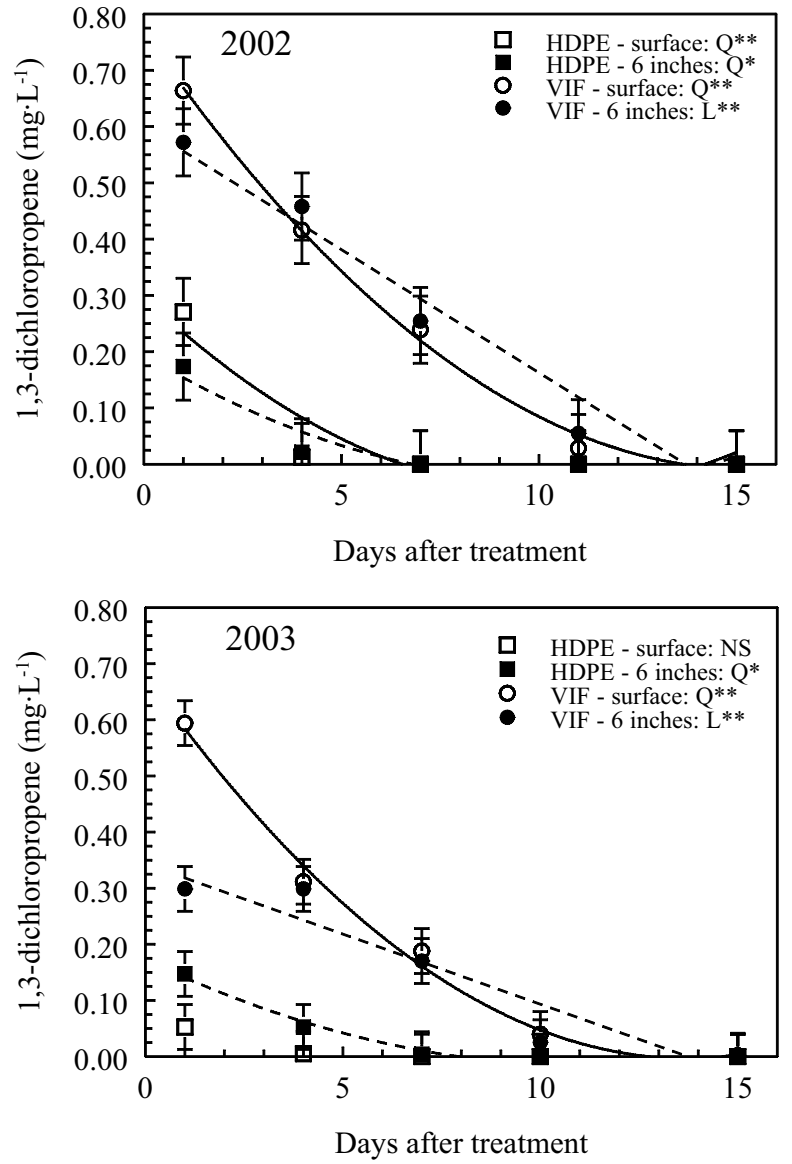

Fig. 4. Effect of film type and depth of chemigation on 1,3-dichloropropene concentration in bed shoulders of a sandy soil. HDPE and VIF are 0.75 -mil highdensity polyethylene film and 1.4-mil virtually impermeable film, respectively. $\mathrm{L}$ and $Q$ indicate linear and quadratic responses, respectively. ${ }^{\mathrm{NS},}{ }^{*},{ }^{* *}$ Nonsignificant and significant at $P \leq 0.05$ and 0.01 , respectively. Solid and dashed lines indicate surface and subsurface chemigation, respectively; $1 \mathrm{mil}=0.0254 \mathrm{~mm}, 1 \mathrm{mg} \cdot \mathrm{L}^{-1}=$ $1 \mathrm{ppm}, 1$ inch $=2.54 \mathrm{~cm}$.
NUTSEDGE CONTROL WITH 1,3DCP AS AFFECTED BY FILM MULCH AND DEPTH OF CHEMIGATION. Nontreated control treatments were conducted with HDPE film and VIF, but only at the 36-inch bed width. Therefore these data were compared only with 36-inch chemigated beds (Table 2). Counts taken on the controls in 2002 did not distinguish between shoulders and centers of beds and are not reported. In 2002, nutsedge density was higher with the VIF control than with the HDPE controls by 60 DAT. However, in 2003, nutsedge density was higher in the VIF controls only at 90 DAT. Compared with the HDPE control, surface chemigation with HDPE film in 2002 resulted in similar nutsedge density in bed centers, but nutsedge density was higher in bed shoulders at 28 and 90 DAT. Nutsedge suppression was somewhat better in bed centers when chemigation was conducted with VIF than with HDPE, so that lower nutsedge densities were obtained with VIF and chemigation than the VIF control at 28 DAT with both surface and subsurface application. However, by 60 DAT only subsurface-treated VIF beds still had a lower nutsedge density than the VIF control, and density with the surface chemigation treatment was no longer significantly different. As for HDPE chemigation in bed shoulders, nutsedge densities were higher with VIF and surface chemigation than with the VIF controls at 28 and 90 DAT,

Table 1. Nutsedge control in a sandy soil chemigated with 1,3-dichloropropene plus chloropicrin as affected by bed width and time.

\begin{tabular}{|c|c|c|c|c|c|c|c|c|c|c|}
\hline \multirow{3}{*}{$\begin{array}{l}\text { Bed width } \\
\text { (inches) }\end{array}$} & \multicolumn{10}{|c|}{ Nutsedge density $\left(\text { plants } / \mathrm{m}^{2}\right)^{\mathrm{z}}$} \\
\hline & \multicolumn{5}{|c|}{2002} & \multicolumn{5}{|c|}{2003} \\
\hline & 14 DAT $^{\mathrm{y}}$ & 28 DAT & $60 \mathrm{DAT}$ & $90 \mathrm{DAT}$ & Significance $^{\mathrm{x}}$ & $14 \mathrm{DAT}$ & $28 \mathrm{DAT}$ & $60 \mathrm{DAT}$ & $90 \mathrm{DAT}$ & Significance \\
\hline \multicolumn{11}{|c|}{ Centers $^{\mathrm{w}}$} \\
\hline 24 & 2.2 & 10.6 & 32.5 & 42.7 & $\mathrm{Q}^{* \star}$ & 4.6 & 17.0 & 70.2 & 65.5 & $\mathrm{Q}^{* *}$ \\
\hline 28 & 1.7 & 10.6 & 21.3 & 26.4 & $\mathrm{Q}^{\star *}$ & 1.2 & 9.0 & 49.7 & 50.1 & $\mathrm{Q}^{* *}$ \\
\hline Significance & NS & $\mathrm{L}^{* *}$ & $\mathrm{~L}^{* *}$ & $\mathrm{~L}^{* *}$ & & NS & $\mathrm{L}^{* *}$ & $\mathrm{Q}^{* *}$ & $\mathrm{Q}^{* *}$ & \\
\hline \multicolumn{11}{|c|}{ Shoulders ${ }^{\mathrm{w}}$} \\
\hline 24 & 19.2 & 83.5 & 112.5 & 120.2 & $\mathrm{Q}^{\star \star}$ & 27.4 & 51.7 & 119.7 & 114.9 & $\mathrm{Q}^{* *}$ \\
\hline 28 & 29.2 & 77.7 & 96.5 & 103.9 & $\mathrm{Q}^{* *}$ & 21.4 & 43.0 & 98.3 & 95.0 & $\mathrm{Q}^{* *}$ \\
\hline 32 & 24.0 & 56.3 & 77.4 & 93.6 & $\mathrm{Q}^{* *}$ & 23.9 & 46.2 & 96.0 & 111.5 & $\mathrm{Q}^{* *}$ \\
\hline
\end{tabular}

${ }^{2} 1$ plant $/ \mathrm{m}^{2}=0.0929 \mathrm{plant} / \mathrm{ft}^{2}$.

yays after treatment.

${ }^{x}$ Responses in columns and rows were evaluated using orthogonal polynomials. ${ }^{\mathrm{N}}$, ${ }^{* *}$ Nonsignificant or significant at $P<0.01$, respectively. $\mathrm{L}$ and $\mathrm{Q}$ indicate linear and quadratic responses, respectively.

wBed center widths were $12,16,20$, and 24 inches for 24-, 28-, 32-, and 36-inch bed widths, respectively, and shoulder width was 6 inches; 1 inch = $2.54 \mathrm{~cm}$. 
Table 2. Comparison of nutsedge density on nontreated beds and beds chemigated with 1,3-dichloropropene plus chloropicrin.

\begin{tabular}{|c|c|c|c|c|c|c|c|c|c|}
\hline \multirow[b]{3}{*}{ Film ${ }^{y}$} & \multirow[b]{3}{*}{ Chemigation $^{\mathrm{x}}$} & \multicolumn{8}{|c|}{ Nutsedge density (plants $\left./ \mathrm{m}^{2}\right)^{\mathrm{z}}$} \\
\hline & & \multicolumn{4}{|c|}{2002} & \multicolumn{4}{|c|}{2003} \\
\hline & & $14 \mathrm{DAT}^{\mathrm{w}}$ & 28 DAT & 60 DAT & $90 \mathrm{DAT}$ & 14 DAT & 28 DAT & 60 DAT & $90 \mathrm{DAT}$ \\
\hline \multicolumn{10}{|c|}{ Centers } \\
\hline HDPE & control & --- & $8.3 \mathrm{ab}$ & $4.8 \mathrm{c}$ & $6.3 \mathrm{~b}$ & $15.1 \mathrm{a}$ & $16.0 \mathrm{ab}$ & $22.0 \mathrm{a}$ & $14.8 \mathrm{~b}$ \\
\hline HDPE & surface & $2.2 \mathrm{a}$ & $6.9 \mathrm{ab}$ & $6.8 \mathrm{bc}$ & $9.9 \mathrm{ab}$ & $2.8 \mathrm{~b}$ & $7.3 \mathrm{bc}$ & $12.3 \mathrm{~b}$ & $9.9 \mathrm{~b}$ \\
\hline VIF & surface & $0 \mathrm{a}$ & $4.7 \mathrm{bc}$ & $10.2 \mathrm{ab}$ & $19.0 \mathrm{a}$ & $0 \mathrm{c}$ & $0.3 \mathrm{~d}$ & $11.7 \mathrm{~b}$ & $11.1 \mathrm{~b}$ \\
\hline VIF & subsurface & $0 \mathrm{a}$ & $1.2 \mathrm{c}$ & $4.0 \mathrm{c}$ & $8.6 \mathrm{~b}$ & $0 \mathrm{c}$ & $0.3 \mathrm{~d}$ & $13.2 \mathrm{~b}$ & $20.5 \mathrm{~b}$ \\
\hline \multicolumn{10}{|c|}{ Shoulders $^{\mathrm{V}}$} \\
\hline HDPE & control & --- & $17.2 \mathrm{~b}$ & $20.5 c$ & $13.2 \mathrm{c}$ & $36.2 \mathrm{a}$ & $57.9 \mathrm{a}$ & $64.2 \mathrm{ab}$ & $51.3 \mathrm{~b}$ \\
\hline HDPE & surface & $46.8 \mathrm{a}$ & $59.2 \mathrm{a}$ & $42.8 \mathrm{abc}$ & $43.4 \mathrm{~b}$ & $48.2 \mathrm{a}$ & $52.3 \mathrm{a}$ & $63.3 \mathrm{ab}$ & $55.9 \mathrm{~b}$ \\
\hline
\end{tabular}

${ }^{2} 1$ plant $/ \mathrm{m}^{2}=0.0929$ plant $/ \mathrm{ft}^{2}$

y HDPE and VIF are 0.75 -mil high-density polyethylene film and 1.4 -mil virtually impermeable film, respectively; $1 \mathrm{mil}=0.0254 \mathrm{~mm}$.

xubsurface chemigation was done at a soil depth of 6 inches; 1 inch $=2.54 \mathrm{~cm}$.

wDays after treatment.

vAll untreated beds were 36 inches wide and were compared with only 36 -inch-wide chemigated beds. Bed center width was 24 inches and shoulder width was 6 inches. Means in columns followed by the same lowercase letter are not significantly different at $P \leq 0.05$.

and nutsedge densities with VIF and subsurface chemigation and the VIF control were similar.

Chemigation was more effective in 2003 than in 2002. In 2003, chemigation with VIF reduced nutsedge density in both centers and shoulders of beds to lower levels than the VIF control at all evaluation dates (Table 2). However, nutsedge density with chemigation and HDPE film was reduced only in centers until 60 DAT, and no suppression was obtained in shoulders. No difference due to drip tape location was observed with either film.

The effects of film and drip-tape location on nutsedge density averaged over all bed widths are presented in Table 3. In 2002, no nutsedge had emerged on centers of beds mulched with VIF by 14 DAT. Surface and subsurface chemigation with HDPE film resulted in nutsedge densities of 3.2 and 2.4 plants $/ \mathrm{m}^{2}$, which were not significantly different. However, by 28 DAT nutsedge on bed centers of HDPE with surface chemigation had increased to 12.2 plants $/ \mathrm{m}^{2}$ and was significantly higher than the 8.1 plants $/ \mathrm{m}^{2}$ obtained with HDPE and subsurface chemigation. Similarly nutsedge density on VIF with surface chemigation at 28 DAT (6.5 plants/ $\mathrm{m}^{2}$ ) was higher than on VIF with subsurface chemigation $\left(3.2\right.$ plants $\left./ \mathrm{m}^{2}\right)$.
However, rate of increase in nutsedge density was greater with VIF than with HDPE later in the season, so that by 90 DAT nutsedge densities were higher on beds mulched with VIF than with HDPE, and the effect of drip tape depth was no longer significant. Hochmuth et al. (2002) reported on only a single evaluation of nutsedge density at 4 weeks after treatment. Consistent with our results for the same time frame, they found greater suppression of nutsedge with VIF than with HDPE film.

On bed shoulders in 2002, at 14 DAT, nutsedge density with VIF film was significantly lower than with HDPE (Table 3). Subsequently, emergence of nutsedge increased through the VIF treatments so by 28 DAT, VIF with surface chemigation and HDPE with subsurface chemigation had similar nutsedge densities. Subsurface chemigation in combination with VIF suppressed nutsedge more effectively than VIF with surface chemigation at 28 DAT, but this difference was not apparent at the subsequent evaluations. Nutsedge density on VIF continued to increase with time so that by 90 DAT nutsedge densities were 116 and 114 plants $/ \mathrm{m}^{2}$ with VIF with surface and subsurface chemigation, respectively, significantly higher than the 74 and 66 plants $/ \mathrm{m}^{2}$ with HDPE and surface and subsurface chemigation.
In 2003, unlike 2002, initial suppression of nutsedge (14 DAT) with HDPE on centers and shoulders of beds was more effective with subsurface chemigation than with surface chemigation (Table 3 ). This difference persisted until 28 DAT on bed centers but not on bed shoulders. Initial infestation of bed centers and shoulders at 14 and 28 DAT was lower with VIF than with HDPE. As in 2002, the suppression did not persist; however, instead of exceeding infestations on HDPE by 90 DAT, in 2003 VIF and HDPE had similar levels of nutsedge infestation. This similarity of infestation levels at 90 DAT and the decline in nutsedge density between 60 and 90 DAT with HDPE may have been due to combination of earlier senescence and dieback due to a natural infestation with a rust (Puccinia sp.) in 2003. No difference in nutsedge infestation between surface and subsurface chemigation occurred with VIF in 2003.

Application of a liquid formulation of 1,3-DCP to a depth of 12 inches with chisels spaced 12 inches apart resulted in significant nutsedge suppression (Hochmuth et al., 2002). This suppression was more effective with VIF than with a low-density polyethylene film. This result suggests that subsurface application of 1,3-DCP via chemigation should 
Table 3. Nutsedge control in a sandy soil chemigated with 1,3-dichloropropene plus chloropicrin as affected by film type, chemigation depth, and time.

\begin{tabular}{|c|c|c|c|c|c|c|c|c|c|c|c|}
\hline \multirow[b]{3}{*}{ Film $^{y}$} & \multirow[b]{3}{*}{ Chemigation $^{\mathrm{x}}$} & \multicolumn{10}{|c|}{ Nutsedge density $\left(\text { plants } / \mathrm{m}^{2}\right)^{\mathrm{z}}$} \\
\hline & & \multicolumn{5}{|c|}{2002} & \multicolumn{5}{|c|}{2003} \\
\hline & & $14 \mathrm{DAT}^{\mathrm{w}}$ & 28 DAT & 60 DAT & 90 DAT & Significance $^{\mathrm{v}}$ & 14 DAT & 28 DAT & 60 DAT & 90 DAT & Significance \\
\hline \multicolumn{12}{|c|}{ Centers $^{\mathrm{u}}$} \\
\hline HDPE & surface & $3.2 \mathrm{a}$ & $12.2 \mathrm{a}$ & $15.5 \mathrm{~b}$ & $17.6 \mathrm{~b}$ & $\mathrm{Q}^{\star *}$ & $6.9 \mathrm{a}$ & $24.7 \mathrm{a}$ & $53.5 \mathrm{a}$ & 38.1 a & $\mathrm{Q}^{* *}$ \\
\hline HDPE & subsurface & $2.4 \mathrm{a}$ & $8.1 \mathrm{~b}$ & $12.3 \mathrm{~b}$ & $14.1 \mathrm{~b}$ & $\mathrm{Q}^{\star *}$ & $1.5 \mathrm{~b}$ & $10.5 \mathrm{~b}$ & $46.7 \mathrm{ab}$ & $41.8 \mathrm{a}$ & $\mathrm{Q}^{\star *}$ \\
\hline \multicolumn{12}{|c|}{ Shoulders ${ }^{\mathrm{u}}$} \\
\hline HDPE & surface & $46.8 \mathrm{a}$ & $81.0 \mathrm{a}$ & $76.6 \mathrm{ab}$ & $74.4 \mathrm{~b}$ & $Q^{\star *}$ & $56.5 \mathrm{a}$ & $81.0 \mathrm{a}$ & $118.4 \mathrm{a}$ & $89.2 \mathrm{a}$ & $Q^{* *}$ \\
\hline HDPE & subsurface & $35.5 \mathrm{a}$ & $73.9 \mathrm{ab}$ & $69.8 \mathrm{~b}$ & $66.1 \mathrm{~b}$ & $\mathrm{Q}^{* *}$ & $32.2 \mathrm{~b}$ & $59.5 \mathrm{a}$ & $107.7 \mathrm{a}$ & $97.1 \mathrm{a}$ & $\mathrm{Q}^{* *}$ \\
\hline VIF & surface & $7.0 \mathrm{~b}$ & $60.0 \mathrm{~b}$ & $97.8 \mathrm{a}$ & $115.9 \mathrm{a}$ & $\mathrm{Q}^{\star *}$ & $1.7 \mathrm{c}$ & $19.6 \mathrm{~b}$ & $76.1 \mathrm{~b}$ & $92.8 \mathrm{a}$ & $\mathrm{Q}^{* *}$ \\
\hline VIF & subsurface & $4.0 \mathrm{~b}$ & $43.3 \mathrm{c}$ & $85.9 \mathrm{ab}$ & $113.9 \mathrm{a}$ & $\mathrm{Q}^{* *}$ & $2.3 \mathrm{c}$ & $13.7 \mathrm{~b}$ & $61.6 \mathrm{~b}$ & $95.6 \mathrm{a}$ & $\mathrm{Q}^{* *}$ \\
\hline
\end{tabular}

${ }^{2} 1$ plant $/ \mathrm{m}^{2}=0.0929$ plant $/ \mathrm{ft}^{2}$.

${ }^{y} \mathrm{HDPE}$ and VIF are 0.75 -mil high-density polyethylene film and 1.4-mil virtually impermeable film, respectively; $1 \mathrm{mil}=0.0254 \mathrm{~mm}$.

xubsurface chemigation was done at a soil depth of 6 inches; 1 inch $=2.54 \mathrm{~cm}$.

wDays after treatment.

"Responses in rows were evaluated using orthogonal polynomials. ${ }^{\mathrm{Ns},}{ }^{\star \star}$ Nonsignificant or significant at $P<0.01$, respectively. Q indicates a quadratic response. Means in columns followed by the same lowercase letter are not significantly different at $P \leq 0.05$

"Bed center widths were $12,16,20$, and 24 inches for 24-, 28-, 32-, and 36-inch bed widths, respectively, and shoulder width was 6 inches.

provide effective suppression with more even distribution. The pattern of emergence of earliest and greatest infestation occurring on bed shoulders with more gradual infestation of bed centers suggests that the nutsedge tubers occurring in the wetted zone were killed by the 1,3-DCP application, but that the concentrations of gaseous 1,3-DCP and its persistence in the bed shoulders were insufficient to control tubers located there. More even distribution of fumigant can be obtained when two drip-tapes are used (Ajwa and Trout, 2004; Desaeger and Csinos, 2005; Desaeger et al., 2004; Fennimore et al., 2003). However, this configuration is more costly for the grower, requires appropriate placement of the two tapes to ensure delivery of a lethal rate to the entire bed, and the positioning of transplants of a doublerow crop such as bell pepper (Capsicum annuиm) requires greater skill.

Even a few nutsedge plants can have an adverse effect on yield, the extent depending on the competitive ability of the crop. As few as 25 purple nutsedge plants $/ \mathrm{m}^{2}$ were sufficient to decrease tomato (Lycopersicon esculentum) yield by $10 \%$; whereas the same number of yellow nutsedge plants doubled the yield reduction to 20\% (Morales-Payan, 1999). In less competitive crops such as bell pepper and watermelon (Citrullus lanatus), yield can be reduced by $10 \%$ by just
5 and 2 yellow nutsedge plants $/ \mathrm{m}^{2}$, respectively (Buker et al., 2003; Motis et al., 2003).

In summary, concentrations of 1,3-D gas in shoulders of beds mulched with HDPE were nonlethal to nutsedge tubers since nutsedge plants emerged within 14 DAT. Concentrations of 1,3-D gas tended to be higher with VIF than with HDPE; this may account for the delay in emergence of nutsedge observed with VIF compared with HDPE. However, even with VIF, in Florida's deep sandy soils, a single drip-tape apparently results in inadequate concentration and time of exposure of nutsedge tubers along bed shoulders. Therefore, the initial nutsedge suppression with VIF did not persist, so that by 90 DAT nutsedge densities with both film types were equivalent or greater with VIF. Narrow bed widths did not eliminate nutsedge emergence on bed shoulders; in fact, the best nutsedge control was obtained with 36-inch beds. However, with 20 plants $/ \mathrm{m}^{2}$ by 14 DAT and greater than 50 plants $/ \mathrm{m}^{2}$ by 90 DAT with 36-inch beds, nutsedge control with 1,3-DCP chemigation can be considered unsatisfactory. It is likely that adequate control of nutsedge can be achieved with 24 -inch beds if 1,3 -DCP were applied for the duration used for the 36-inch beds; however, this would result in an application that exceeds the current recommended rate.

\section{Literature cited}

Ajwa, H.A. and T. Trout. 2004. Drip application of alternative fumigants to methyl bromide for strawberry production. HortScience 39:1707-1715

Ajwa, H.A., T. Trout, J. Mueller, S. Wilhelm, S.D. Nelson, R. Soppe, and D. Shatley. 2002. Application of alternative fumigants through drip irrigation systems. Phytopathology 92:1349-1355.

Buker III, R.S., W.M. Stall, S.M. Olson, and D.G. Schilling. 2003. Season-long interference of yellow nutsedge (Cyperus esculentus) with direct-seeded and transplanted watermelon (Citrullus lanatus). Weed Technol. 17:751-754.

Csinos, A.S., J.E. Laska, and S. Childers. 2002. Dye injection for predicting pesticide movement in micro-irrigated polyethylene film mulch beds. Pest Mgt. Sci. 58:381-384.

Desaeger, J.A.J., J.E. Eger Jr., A.S. Csinos, J.P. Gilreath, S.M. Olson, and T.M. Webster. 2004. Movement and biological activity of drip-applied 1,3-dichloropropene and chloropicrin in raised mulched beds in the southeastern USA. Pest Mgt. Sci. 60:1220-1230.

Fennimore, S.A., M.J. Haar, and H.A. Ajwa. 2003. Weed control in strawberry provided by shank- and drip-applied methyl bromide alternative fumigants. HortScience 38:55-61.

Gilreath, J.P., J.W. Noling, and B.M. Santos. 2004. Methyl bromide alternatives for bell pepper (Capsicum annuum) and 
cucumber (Cucumis sativus) rotations. Crop Protection 23:347-351.

Gilreath, J.P. and B.M. Santos. 2004a. Efficacy of methyl bromide alternatives on purple nutsedge (Cyperus rotundus) control in tomato and pepper. Weed Technol. 18:341-345.

Gilreath, J.P. and B.M. Santos. 2004b. Methyl bromide alternatives for weed and soilborne disease management in tomato (Lycopersicon esculentum). Crop Protection 23:1193-1198.

Gilreath, J.P. and B.M. Santos. 2005. Efficacy of 1,3-dichloropropene plus chloropicrin in combination with herbicides on purple nutsedge (Cyperusrotundus) control in tomato. Weed Technol. 19:137-140.

Hochmuth, R.C., W.E. Davis, W.M. Stall, E.H. Simonne, and A.W. Weiss. 2002. Evaluating nutsedge control (Cyperusspp.) with various formulations and rates of 1,3 dichloropropene chemigated using drip tape under two polyethylene mulches. Proc. Fla. State Hort. Soc. 115: 195-196.

Hutchinson, C.M., M.E. McGiffen, Jr., J.J. Sims, and J.O. Becker. 2004. Fumigant combinations for Cyperus esculentum L. control. Pest Mgt. Sci. 60: 369-374.

Locascio, S.J., J.P. Gilreath, D.W. Dickson, T.A. Kucharek, J.P. Jones, and J.W. Noling. 1997. Fumigant alternatives to methyl bromide for polyethylene-mulched tomato. HortScience 32:1208-1211.

Morales-Payan, J.P. 1999. Interference of purple and yellow nutsedges (Cyperus rotundus L. and Cyperusesculentus L.) with tomato (Lycopersicon esculentum Mill.). PhD Diss., Horticultural Sciences Dept., Univ. of Florida, Gainesville.

Motis, T.N., S.J. Locascio, and J.P. Gilreath. 2002. Efficacy of 1,3-dichloropropene + chloropicrin and metam-Na on yellow nutsedge tubers planted at varying growth stages. Proc. Fla. State Hort. Soc. 115:189-192.

Motis, T.N., S.J. Locascio, J.P. Gilreath, and W.M. Stall. 2003. Season-long interference of yellow nutsedge (Cyperus esculentus) with polyethylene-mulched bell pepper (Capsicum annuиm). Weed Technol. 17:543-549.

Nelson, S.D., L.H. Allen, Jr., J. Gan, C. Riegel, D.W. Dickson, S.J. Locascio, and D.J. Mitchell. 2000. Can virtually impermeable films reduce the amount of fumigant required for pest-pathogen management in high value crops? Soil Crop Sci. Soc. Fla. Proc. 59:85-89.

Nelson, S.D., C. Riegel, L.H. Allen, Jr., D.W. Dickson, J. Gan, S.J. Locascio, and D.J. Mitchell. 2001. Volatilization of 1,3dichloropropene in Florida plasticulture and effects on fall squash production. J. Amer. Soc. Hort. Sci. 126:496-502.

Papiernik, S.K., S.R. Yates, R.S. Dungan, S.M. Lesch, W. Zheng, and M. Guo. 2004. Effect of surface tarp on emmissions and distribution of drip-applied fumigants. Environ. Sci. Technol. 38:4254-4262.

Santos, B.M. and J.P. Gilreath. 2003. Length of irrigation and soil humidity as basis for delivering fumigants through drip lines in Florida spodosols. Proc. Fla. State Hort. Soc. 116:85-87.

Santos B.M., J.P. Gilreath, and T.N. Motis. 2005. Managing nutsedge and stunt nematode in pepper with reduced methyl bromide plus chloropicrin rates under virtually impermeable films Hort Technology 15: 596-599.

Simonne, E., D. Studstill, and R.C. Hochmuth. 2006. Understanding water movement in mulched beds on sandy soils: an approach to ecologically sound fertigation in vegetable production. Acta Hort. 700:173-178.

Wang, D. and S.R. Yates. 1998. Methyl bromide emission from fields partially covered with a high-density polyethylene and a virtually impermeable film. Environ. Sci. Technol. 32:2515-2518.

Wang, D., S.R. Yates, F.F. Ernst, and J.A. Knuteson. 2001. Volatilization of 1,3dichloropropene under different application methods. Water Air Soil Pollution 127:109-123.

Wang, D., S.R. Yates, J. Gan, and J.A. Knuteson. 1999. Atmospheric volatilization of methyl bromide, 1,3-dichloropropene, and propargyl bromide through two plastic films: transfer coefficient and temperature effect. Atmospheric Environ. 33:401-407.

Yates, S.R., J. Gan, S.K. Papiernik, R. Dungan, and D. Wang. Reducing fumigant emissions after soil application. Phytopathology 92:1344-1348. 